\title{
Analisis Kestabilan dan Kontrol Optimal pada Model Dinamik Penyebaran Penyakit Malaria
}

\author{
Retna Shely Purwanti dan Mardlijah \\ Departemen Matematika, Fakultas Matematika, Komputasi, dan Sains Data \\ Institut Teknologi Sepuluh Nopember (ITS) \\ e-mail: retnashely88@gmail.com
}

\begin{abstract}
Abstrak-Malaria adalah suatu penyakit yang disebabkan oleh parasit Plasmodium yang ditularkan oleh gigitan nyamuk Anopheles betina. Hampir separuh populasi dunia hidup dalam risiko penyakit ini dengan lebih dari 300 juta orang terjangkit malaria setiap tahun. Dalam studi ini, digunakan model penyebaran penyakit malaria yang terdiri dari dua populasi yang dibagi menjadi beberapa sub-populasi antara lain sub-populasi manusia Susceptible, sub-populasi manusia Exposed, subpopulasi manusia Infected, sub-populasi manusia Recovered, sub-populasi nyamuk Susceptible, sub-populasi nyamuk Exposed, dan sub-populasi nyamuk Infected. Model dianalisis dengan menentukan titik kesetimbangan bebas penyakit dan endemik, serta kestabilan dari setiap titik kesetimbangan. Kemudian dilakukan kontrol optimal menggunakan Prinsip Maksimum Pontryagin dan disimulasikan dengan menggunakan Matlab. Hasil simulasi menunjukan menurunnya sub-populasi manusia dan populasi nyamuk yang terinfeksi parasit Plasmodium setelah adanya pemberian kontrol penyemprotan insektisida dan pengobatan dengan nilai fungsi objektif sebesar 1.5556 .
\end{abstract}

Kata Kunci-Model Penyebaran Penyakit Malaria, Kestabilan, Kontrol Optimal, Prinsip Maksimum Pontryagin.

\section{PENDAHULUAN}

$\mathrm{M}$ ALARIA adalah suatu penyakit yang disebabkan oleh parasit Plasmodium yang ditularkan oleh gigitan nyamuk Anopheles betina [1]. Situasi malaria di kawasan hutan masih menjadi masalah serius karena nyamuk yang sangat efisien, penularan nyamuk dan perpindahan penduduk yang tidak terkendali. Selain itu, ada bukti yang menunjukkan bahwa perubahan iklim dan meningkatnya pengendapan suhu bumi akan mempercepat pematangan parasit pada nyamuk, meningkatknya frekuensi menggigit nyamuk dan menciptakan kondisi yang menyebabkan perkembangbiakan nyamuk semakin cepat [2]

Malaria dapat ditemukan mulai dari belahan bumi utara (Amerika Utara sampai Eropa dan Asia) ke belahan bumi selatan (Amerika Selatan); mulai dari daerah dengan ketinggian $2850 \mathrm{~m}$ sampai dengan daerah yang letaknya $400 \mathrm{~m}$ di bawah permukaan laut. Keadaan malaria di dunia saat ini diperkirakan terdapat 300-500 juta kasus malaria klinis/tahun dengan 1,5-2,7 juta kematian, terutama negara-negara benua Afrika. Risiko tinggi penularan malaria di Afrika dengan jumlah estimasi kasus pada tahun 2010 sekitar 174 kasus dengan estimasi kematian sebanyak 596.000 kasus. Sebanyak 90\% kematian terjadi pada anak-anak dengan rasio 1: 4 anak balita di Afrika meninggal karena malaria. Sedangkan di

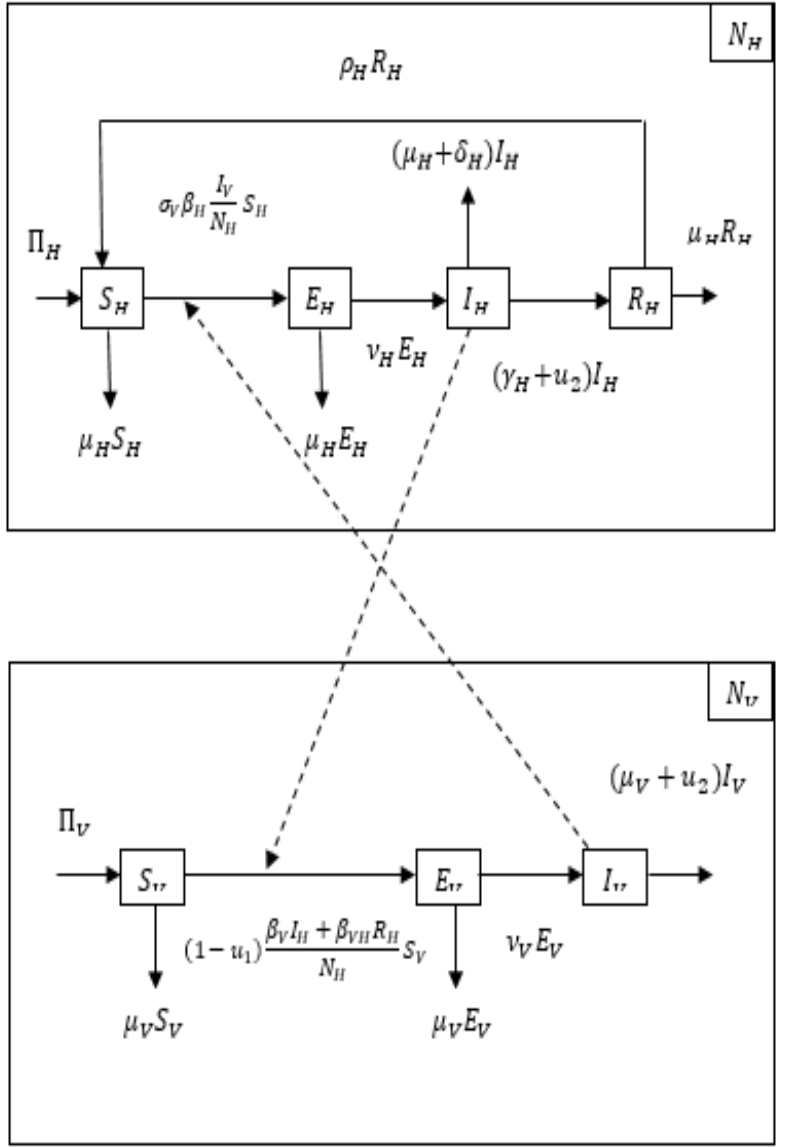

Gambar 1. Diagram kompartemen model dinamik penyebaran penyakit malaria.

Indonesia, pada tahun 2006 terdapat sekitar 2 juta kasus malaria klinis, sedangkan tahun 2007 menjadi 1,75 juta kasus. Jumlah penderita positif malaria tahun 2006 sekitar 350 ribu kasus, dan pada tahun 2007 sekitar 311 ribu kasus [3].

Melihat fenomena tersebut, perlu adanya model matematika pada penyebaran penyakit malaria, sehingga dari model tersebut dapat dianalisis kestabilan penyebaran penyakit tersebut dan dapat dirancang kontrol optimal dengan berbagai faktor yang ada sesuai dengan fungsi tujuan yang diinginkan. Dalam penelitian ini, dianalisis kestabilan model dinamik penyebaran penyakit malaria, serta dikontrol dengan beberapa faktor upaya yang dibutuhkan menggunakan prinsip Maksimum Pontryagin. Sehingga, dengan adanya kontrol optimal tersebut dapat ditentukan strategi yang optimal untuk dapat mengendalikan penyebaran penyakit malaria tersebut. 
Tabel 1.

Variabel pada Model Matematika Penyebaran Penyakit Malaria

\begin{tabular}{|c|c|c|c|}
\hline Variabel & Keterangan & $\begin{array}{l}\text { Nilai } \\
\text { Awal } \\
\end{array}$ & Sumber \\
\hline$S_{H}(t)$ & $\begin{array}{l}\text { Kumpulan individu rentan } \\
\text { terinfeksi penyakit (Susceptible } \\
\text { Host). }\end{array}$ & 600 & [4] \\
\hline$E_{H}(t)$ & $\begin{array}{l}\text { Kumpulan individu yang sudah } \\
\text { terinfeksi malaria namun tidak } \\
\text { tahu jika sedang terinfeksi } \\
\text { (Exposed Host). }\end{array}$ & 200 & [4] \\
\hline$I_{H}(t)$ & $\begin{array}{l}\text { Kumpulan individu yang sudah } \\
\text { terinfeksi malaria (Infected Host) }\end{array}$ & 20 & [4] \\
\hline$R_{H}(t)$ & $\begin{array}{l}\text { Kumpulan individu dalam masa } \\
\text { penyembuhan (Recovered Host). }\end{array}$ & 10 & [4] \\
\hline$S_{V}(t)$ & $\begin{array}{l}\text { Kumpulan nyamuk rentan } \\
\text { terhadap parasit Plasmodium } \\
\text { (Susceptible Vector). }\end{array}$ & 7050 & [4] \\
\hline$E_{V}(t)$ & $\begin{array}{l}\text { Kumpulan nyamuk yang sudah } \\
\text { terinfeksi parasit Plasmodium } \\
\text { namun belum bisa menginfeksi } \\
\text { (Exposed Vector) }\end{array}$ & 20 & [4] \\
\hline$I_{V}(t)$ & $\begin{array}{l}\text { Kumpulan nyamuk yang sudah } \\
\text { terinfeksi parasit Plasmodium } \\
\text { (Infected Vector). }\end{array}$ & 15 & [4] \\
\hline
\end{tabular}

Tabel 2.

Parameter pada Model Matematika Penyebaran Penyakit Malaria

\begin{tabular}{|c|c|c|c|}
\hline $\begin{array}{l}\text { Para- } \\
\text { meter }\end{array}$ & Keterangan & Nilai & Sumber \\
\hline$\Pi_{H}$ & $\begin{array}{l}\text { Rate pertumbuhan hidup } \\
\text { manusia }\end{array}$ & $\begin{array}{l}0.00001 \\
1\end{array}$ & {$[5]$} \\
\hline$\rho_{H}$ & $\begin{array}{l}\text { Rate individu manusia recovered } \\
\text { karena sistem imun }\end{array}$ & 0.0146 & [4] \\
\hline$\sigma_{V}$ & $\begin{array}{l}\text { Rate individu manusia terkena } \\
\text { gigitan nyamuk }\end{array}$ & 0.5 & [4] \\
\hline$\beta_{H}$ & $\begin{array}{l}\text { Rate transmisi parasit dari } \\
\text { individu nyamuk infected }\end{array}$ & 0.4 & {$[4]$} \\
\hline$\mu_{H}$ & Rate kematian alami manusia & 0.00004 & {$[4]$} \\
\hline$v_{H}$ & $\begin{array}{l}\text { Rate rata penyembuhan manusia } \\
\text { exposed menjadi infected }\end{array}$ & 0.2 & [4] \\
\hline$\gamma_{H}$ & $\begin{array}{l}\text { Rate individu manusia infected } \\
\text { menjadi recovered }\end{array}$ & 0.05 & {$[4]$} \\
\hline$\delta_{H}$ & $\begin{array}{l}\text { Rate kematian individu manusia } \\
\text { akibat terjangkit malaria }\end{array}$ & $\begin{array}{l}0.00345 \\
4\end{array}$ & {$[4]$} \\
\hline$\Pi_{V}$ & $\begin{array}{l}\text { Rate pertumbuhan hidup } \\
\text { nyamuk }\end{array}$ & 0.2 & {$[5]$} \\
\hline$\beta_{V}$ & $\begin{array}{l}\text { Rate transmisi parasit nyamuk } \\
\text { dari individu manusia infected }\end{array}$ & 0.3 & [4] \\
\hline$\beta_{V H}$ & $\begin{array}{l}\text { Rate kontak nyamuk dengan } \\
\text { manusia }\end{array}$ & 0.03 & {$[4]$} \\
\hline$v_{V}$ & $\begin{array}{l}\text { Rate rata penyembuhan nyamuk } \\
\text { exposed menjadi infected }\end{array}$ & 0.1 & [4] \\
\hline$\mu_{V}$ & Rate kematian alami nyamuk & 0.0714 & [4] \\
\hline$u_{1}$ & $\begin{array}{l}\text { Kontrol penyemprotan } \\
\text { insektisida terhadap nyamuk }\end{array}$ & 30 & Asumsi \\
\hline$u_{2}$ & $\begin{array}{l}\text { Kontrol pengobatan terhadap } \\
\text { individu manusia yang terinfeksi. }\end{array}$ & 40 & Asumsi \\
\hline
\end{tabular}

\section{MODEL DINAMIK PENYEBARAN PENYAKIT MALARIA}

Model dinamik penyebaran penyakit malaria yang dibahas pada jurnal ini adalah model dinamik yang digunakan Roop-O $d k k$ [4] yang meninjau dua populasi, yaitu populasi host (penderita atau manusia) yang dinotasikan $N_{H}$ dan vector (penular atau nyamuk) yang dinotasikan $N_{V}$. Selanjutnya, model dikontruksi dengan menambahkan strategi kontrol yang diinginkan. Adapun strategi kontrol yang digunakan dalam
Studi ini, yaitu penyemprotan insektisida dan pengobatan individu yang terinfeksi pada model penyebaran penyakit malaria. Berikut ini diberikan beberapa asumsi yang digunakan dalam strategi kontrol pada model penyebaran penyakit malaria, yaitu:

1. Kontrol $u_{1}$ merupakan penyemprotan insektisida pada nyamuk terutama nyamuk yang berparasit Plasmodium. Karena nyamuk berkembangbiak lebih cepat pada musim hujan dan iklim yang panas [2], sehingga diperlukan usaha yang lebih dalam penyemprotan insektisida. Dengan demikian, tingkat reproduksi populasi nyamuk berkurang dengan faktor $1-u_{1}$.

2. Strategi kontrol $u_{2}$ merupakan proporsi pemberian obat malaria. Diasumsikan $u_{2} I_{H}$ adalah pengobatan terhadap individu yang terinfeksi.

Sehubungan dengan asumsi yang mendasari ini, model kontrol optimal untuk penyebaran penyakit malaria yang menyimpulkan strategi pencegahan dan pengobatan digambarkan dengan diagram kompartemen model dinamik penyebaran penyakit malaria, sebagai pada Gambar 1 .

Berdasarkan diagram kompartemen pada Gambar 1, model matematika penyebaran penyakit malaria dapat disajikan dalam sistem persamaan diferensial sebagai berikut:

$\frac{d S_{H}}{d t}=\Pi_{H}+\rho_{H} R_{H}-\sigma_{V} \beta_{H} \frac{I_{V}}{N_{H}} S_{H}-\mu_{H} S_{H}$

$\frac{d E_{H}}{d t}=\sigma_{V} \beta_{H} \frac{I_{V}}{N_{H}} S_{H}-\left(v_{H}+\mu_{H}\right) E_{H}$

$\frac{d I_{H}}{d t}=v_{H} E_{H}-\left(\gamma_{H}+\mu_{H}+\delta_{H}+u_{2}\right) I_{H}$

$\frac{d R_{H}}{d t}=\gamma_{H} I_{H}-\left(\rho_{H}+\mu_{H}\right) R_{H}+u_{2} I_{H}$

$\frac{d S_{V}}{d t}=\Pi_{V}-\left(1-u_{1}\right) \sigma_{V}\left(\frac{\beta_{V} I_{H}+\beta_{V H} R_{H}}{N_{H}}\right) S_{V}-\mu_{V} S_{V}$

$\frac{d E_{V}}{d t}=\left(1-u_{1}\right) \sigma_{V}\left(\frac{\beta_{V} I_{H}+\beta_{V H} R_{H}}{N_{H}}\right) S_{V}-\left(\nu_{V}+\mu_{V}\right) E_{V}$

$\frac{d I_{V}}{d t}=v_{V} E_{V}-\left(\mu_{V}+u_{1}\right) I_{V}$

dimana $\quad N_{H}(t)=S_{H}(t)+E_{H}(t)+I_{H}(t)+R_{H}(t) \quad$ dan $N_{V}(t)=S_{V}(t)+E_{V}(t)+I_{V}(t)$

Adapun notasi serta definisi dari variabel dan masing-masing parameter yang digunakan pada model matematika penyebaran penyakit malaria tertera pada Tabel 1 dan 2:

\section{ANALISIS DAN PEMBAHASAN}

\section{A. Analisis Model Penyebaran Penyakit Malaria}

Pada analisis model penyebaran penyakir malaria ditentukan titik kesetimbangan dan bilangan reproduksi dasar. Titik kesetimbangan sistem dinamis yang dinyatakan oleh suatu persamaan differensial biasa merupakan solusi dari sistem yang tidak berubah terhadap waktu. Misal, diberikan suatu persamaan differensial.

$$
\dot{x}(t)=f(x(t)), \quad x\left(t_{o}\right)=x_{0}
$$




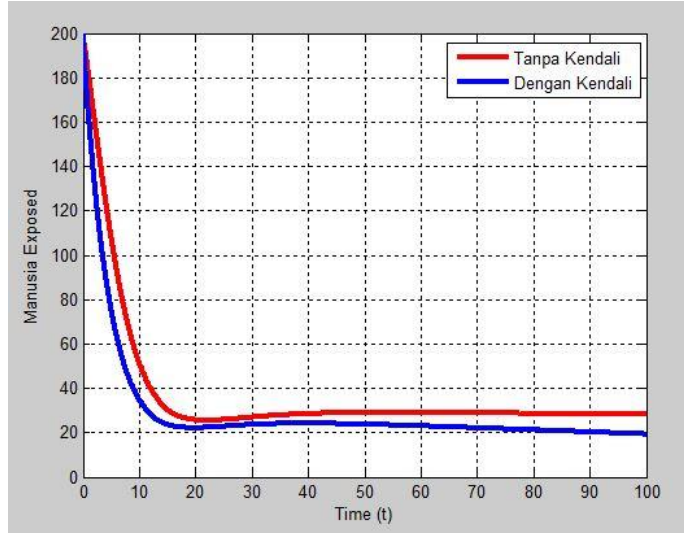

Gambar 2. Grafik sub-populasi manusia exposed sebelum dan sesudah dikontrol.

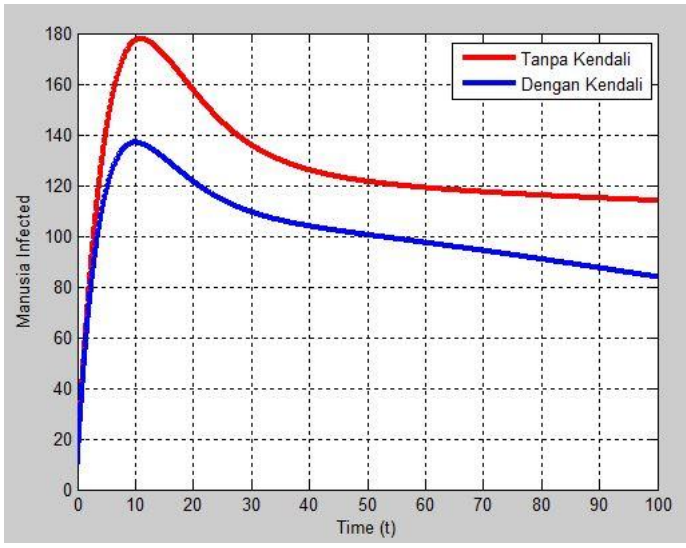

Gambar 3. Grafik Sub-populasi manusia infected sebelum dan sesudah dikontrol.

dengan $x(t) \in R^{n}$, vektor $\bar{x}$ yang memenuhi $f(\bar{x})=0$.

Definisi 3.1

Titik $\bar{x} \in \mathbb{R}^{n}$ disebut titik kesetimbangan dari suatu sistem jika $f(\bar{x})=0 \quad[6]$

Untuk titik kesetimbangan diperoleh pada laju masingmasing kompartemen samadengan nol. Untuk titik kesetimbangan bebas penyakit sub-populasi manusia yang terinfeksi malaria samadengan nol $\left(I_{H}=0\right)$ dan juga subpopulasi nyamuk yang terinfeksi malaria samadengan nol $\left(I_{V}=0\right)$. Sehingga, diperoleh titik kesetimbangan bebas penyakit yaitu

$$
\begin{aligned}
E_{0} & =\left(S_{H}^{0}, E_{H}^{0}, I_{H}^{0}, R_{H}^{0}, S^{0}{ }_{V}, E_{V}^{0}{ }_{V}, I_{V}^{0}\right) \\
& =\left(\frac{\Pi_{H}}{\mu_{H}}, 0,0,0, \frac{\Pi_{V}}{\mu_{V}}, 0,0\right) .
\end{aligned}
$$

Untuk titik kesetimbangan endemik sub-populasi manusia yang terinfeksi malaria tidak sama dengan nol $\left(I_{H} \neq 0\right)$ dan juga sub-populasi nyamuk yang terinfeksi malaria tidak sama dengan nol $\left(I_{V} \neq 0\right)$. Sehingga, diperoleh titik kesetimbangan endemik yaitu

dimana:

$$
E=\left(S_{H}^{*}, E^{*}{ }_{H}, I^{*}{ }_{H}, R^{*}{ }_{H}, S^{*}{ }_{V}, E^{*}{ }_{V}, I^{*}{ }_{V}\right)
$$

$S_{H}^{*}=\frac{\Pi_{H}\left(\Pi_{H}+\rho_{H}\right) R^{*}{ }_{H}}{\sigma_{V} \beta_{H} \mu_{H} I_{V}^{*}-\mu_{H} \Pi_{H}}$

$E^{*}{ }_{H}=\frac{\sigma_{V} \beta_{H} \mu_{H} I^{*}{ }_{V}}{\Pi_{H}\left(v_{H}+\mu_{H}\right)} S^{*}{ }_{H}$

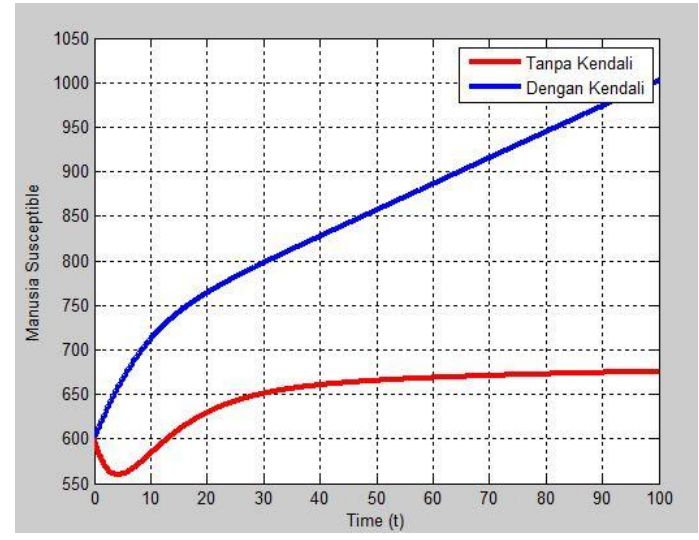

Gambar 4. Grafik sub-populasi manusia susceptible sebelum dan sesudah dikontrol.

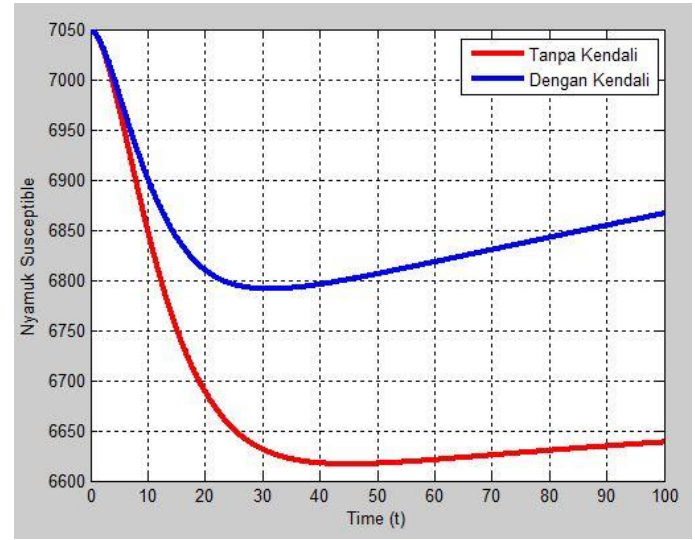

Gambar 5. Grafik Sub-populasi nyamuk susceptible sebelum dan sesudah dikontrol.

$I^{*}{ }_{H}=\frac{v_{H} E^{*}{ }_{H}}{\gamma_{H}+\mu_{H}+\delta_{H}+u_{2}}$

$R^{*}{ }_{H}=\frac{\left(\gamma_{H}+u_{2}\right) I^{*}{ }_{H}}{\rho_{H}+\mu_{H}}$

$S^{*}{ }_{V}=\frac{\Pi_{V}{ }^{2}}{\left(1-u_{1}\right) \sigma_{V} \mu_{H}\left(\beta_{V} I^{*}{ }_{H}+\beta_{V H} R_{H}^{*}\right)-\mu_{V} \Pi_{H}}$

$E_{V}^{*}=\frac{\left(1-u_{1}\right) \sigma_{V} \mu_{H}\left(\beta_{V} I^{*}{ }_{H}+\beta_{V H} R_{H}^{*}\right) S_{V}^{*}}{\Pi_{V}\left(v_{V}+\mu_{V}\right)}$

$I_{V}^{*}=\frac{v_{V} E^{*}{ }_{V}}{\mu_{V}+u_{1}}$

Untuk menganalisis kestabilan lokal pada setiap titik kesetimbangan perlu dilakukan linierisasi dengan menggunakan matriks Jacobian. Matriks Jacobian $J(f(\bar{x}))$ dapat digunakan untuk mengidentifikasi sifat kestabilan sistem nonlinier disekitar titik setimbang $\bar{x}$ dimana titik setimbang tersebut disubtitusikan ke dalam persamaan matriks Jacobian sehingga diperoleh nilai-nilai eigennya $(\lambda)$ dari persamaan karakteristik $\operatorname{det}(A-\lambda I)=0$.

Didapatkan matriks Jacobian dari sistem yaitu

$$
J=\left(\begin{array}{ccccc}
-a_{1}-\mu_{H} & 0 & 0 & \rho & 0 \\
a_{1} & -a_{3} & 0 & 0 & 0 \\
0 & v_{H} & -a_{3}-a_{4} & 0 & 0 \\
0 & 0 & a_{4} & -a_{6} & 0 \\
0 & 0 & 0 & -a_{7} & -a_{8}-\mu_{v} \\
0 & 0 & 0 & a_{7} & a_{8} \\
0 & 0 & 0 & 0 & 0
\end{array}\right.
$$




$$
\left.\begin{array}{cc}
0 & -a_{2} \\
0 & a_{2} \\
0 & 0 \\
0 & 0 \\
0 & -a_{9} \\
-a_{10} & a_{9} \\
v_{V} & -a_{11}
\end{array}\right)
$$

dimana:

$$
\begin{array}{ll}
a_{1}=\sigma_{V} \beta_{H} \frac{I_{V}}{N_{H}} & a_{7}=\frac{\left(1-u_{1}\right) \sigma_{V} \beta_{V H} S_{H}}{N_{H}} \\
a_{2}=\sigma_{V} \beta_{H} \frac{S_{H}}{N_{H}} & a_{8}=\left(1-u_{1}\right) \sigma_{V}\left(\frac{\beta_{V} I_{H}+\beta_{V H} R_{H}}{N_{H}}\right) \\
a_{3}=v_{H}+\mu_{H} & a_{9}=\frac{\left(1-u_{1}\right) \sigma_{V} \beta_{V} S_{H}}{N_{H}} \\
a_{4}=\gamma_{H}+u_{2} & a_{10}=v_{V}+\mu_{V} \\
a_{5}=\mu_{H}+\delta_{H} & a_{11}=\mu_{V}+u_{1} \\
a_{6}=\rho_{H}+\mu_{H} &
\end{array}
$$

Seperti langkah pada analisis kestabilan titik setimbang non endemik, dengan mengevaluasi nilai titik setimbang $E_{0}$ sehingga diperoleh persamaan karakteristik titik setimbang endemik malaria:

$\left(\lambda+\mu_{H}\right)\left(\lambda+b_{1}\right)\left(\lambda+b_{2}+b_{3}\right)\left(\lambda+b_{4}\right)\left(\lambda+\mu_{V}\right)(\lambda+$ $\left.b_{5}\right)\left(\lambda+b_{6}\right)=0$

Didapatkan beberapa nilai eigen, antara lain:

$\lambda_{1}=-\mu_{H}$

$\lambda_{2}=-b_{1}=-\left(v_{H}+\mu_{H}\right)$

$\lambda_{3}=-b_{2}-b_{3}=-\left(\gamma_{H}+\mu_{H}+\delta_{H}+u_{2}\right)$

$\lambda_{4}=-b_{4}=-\left(\rho_{H}+\mu_{H}\right)$

$\lambda_{5}=-\mu_{V}$

$\lambda_{6}=-b_{5}=-\left(v_{V}+\mu_{V}\right)$

$\lambda_{7}=-b_{6}=-\left(\mu_{V}+u_{1}\right)$

Dari persamaan karakteristik diatas tersebut terlihat bahwa nilai eigen $\lambda_{1}, \lambda_{2}, \lambda_{3}, \lambda_{4}, \lambda_{5}, \lambda_{6}, \lambda_{7}<0$, dan karena semua parameter bernilai positif maka titik setimbang bebas penyakit (non endemik) dapat dikatakan stabil.

Seperti langkah pada analisis kestabilan titik setimbang non endemik, dengan mengevaluasi nilai titik setimbang $E$ sehingga diperoleh persamaan karakteristik titik setimbang endemik malaria

$\lambda^{7}+P_{1} \lambda^{6}+P_{2} \lambda^{5}+P_{3} \lambda^{4}+P_{4} \lambda^{3}+P_{5} \lambda^{2}+P_{6} \lambda+P_{7}=0$

Berdasarkan kriteria Routh-Hurwitz, Persamaan ini akan memiliki akar-akar yang negatif jika dan hanya jika

$\leftrightarrow P_{1}, P_{2}, P_{3}, P_{4}, P_{5}, P_{6}, P_{7}>0$

$\leftrightarrow\left(P_{1} P_{2}-P_{3}\right) P_{3}>P_{1}\left(P_{1} P_{4}-P_{5}\right)$

$\leftrightarrow\left(\frac{P_{1} P_{4}-P_{5}}{P_{1}}\right)>\left(\frac{P_{1} P_{2}-P_{3}}{P_{1}}\right)\left(\frac{\left(P_{1} P_{2}-P_{3}\right) P_{5}-P_{1}\left(P_{1} P_{6}-P_{7}\right)}{\left(P_{1} P_{2}-P_{3}\right) P_{3}-P_{1}\left(P_{1} P_{4}-P_{5}\right)}\right)$

\section{B. Kontrol Optimal dengan Prinsip Maksimum Pontryagin}

Dalam menyelesaikan permasalahan kontrol optimal, salah satu metode yang dapat digunakan adalah prinsip maksimum Pontryagin. Prinsip maksimum pontryagin merupakan suatu kondisi sehingga dapat diperoleh penyelesaian kontrol optimal yang sesuai dengan tujuan (memaksimalkan indeks performansi) [7].

Pada masalah kontrol optimal model penyebaran penyakit malaria, tujuan yang akan dicapai adalah meminimumkan penyebaran penyakit malaria dengan diberikan tindakan kontrol $u_{1}(t)$ dan $u_{2}(t)$. Kontrol $u_{1}(t)$ yaitu kontrol kontrol terhadap penyemprotan insektisida untuk dapat meminimumkan jumlah populasi nyamuk. Dan kontrol $u_{2}(t)$ yaitu kontrol untuk pengobatan individu yang sudah terinfeksi.

Penyelesaian kontrol optimal model penyebaran penyakit malaria menggunakan Prinsip Maksimum Pontryagin dan fungsi objektif untuk model diberikan:

$$
\begin{aligned}
& J\left(u_{1}, u_{2}\right)=\min \int_{t 0}^{t f}\left(I_{H}(t)+I_{v}(t)+\left(\frac{C_{1} u_{1}^{2}}{2}+\right.\right. \\
& \left.\left.\frac{C_{2} u_{2}^{2}}{2}\right)\right) d t
\end{aligned}
$$

dengan kendala:

$$
\begin{aligned}
& 0 \leq t \leq t_{f} \\
& 0 \leq u_{1} \leq 1 \\
& 0 \leq u_{2} \leq 1
\end{aligned}
$$

dimana:

$C_{1}$ : bobot pada kontrol penyemprotan insektisida

$C_{2}$ : bobot pada kontrol pengobatan individu terinfeksi

Untuk menyelesaikan kontrol optimal, Langkah langkah penyelesaian:

1. Bentuk fungsi Hamiltonian

$$
\begin{aligned}
H= & I_{H}(t)+I_{v}(t)+\left(\frac{C_{1} u_{1}^{2}}{2}+\frac{C_{2} u_{2}^{2}}{2}\right)+ \\
& \lambda_{S_{H}}\left(\Pi_{H}+\rho_{H} R_{H}-\sigma_{V} \beta_{H} \frac{I_{V}}{N_{H}} S_{H}-\mu_{H} S_{H}\right)+ \\
& \lambda_{E_{H}}\left(\sigma_{V} \beta_{H} \frac{I_{V}}{N_{H}} S_{H}-\left(v_{H}+\mu_{H}\right) E_{H}\right)+ \\
& \lambda_{I_{H}}\left(v_{H} E_{H}-\left(\gamma_{H}+\mu_{H}+\delta_{H}+u_{2}\right) I_{H}\right)+ \\
& \lambda_{R_{H}}\left(\left(\gamma_{H}+u_{2}\right) I_{H}-\left(\rho_{H}+\mu_{H}\right) R_{H}\right)+ \\
& \lambda_{S_{V}}\left(\Pi_{V}-\left(1-u_{1}\right) \sigma_{V}\left(\frac{\beta_{V} I_{V}+\beta_{V H} R_{H}}{N_{H}}\right) S_{V}-\mu_{V} S_{V}+\right. \\
& \lambda_{E_{V}}\left(1-u_{1}\right) \sigma_{V}\left(\frac{\beta_{V} I_{V}+\beta_{V H} R_{H}}{N_{H}}\right) S_{V}-\left(v_{V}+\mu_{V}\right) E_{V}+ \\
& \lambda_{I_{V}}\left(v_{V} E_{V}-\left(\mu_{V}+u_{2}\right) I_{V}\right)
\end{aligned}
$$

2. Menentukan kondisi stasioner dari persamaan (3.1) untuk mendapatkan persamaan kontrol optimal. Persamaan (3.1) diturunkan terhadap $u_{1}$ dan $u_{2}$, sehingga diperoleh

$$
\begin{aligned}
& \text { a. } \frac{\partial H}{\partial u_{1}}=0 \\
& C_{1} u_{1}{ }^{*}+\left(\lambda_{E_{V}}-\lambda_{S_{V}}\right) \sigma_{V}\left(\frac{\beta_{V} I_{V}+\beta_{V H} R_{H}}{N_{H}}\right) S_{V}+\lambda_{I_{H}} I_{V}= \\
& 0 \\
& C_{1} u_{1}{ }^{*}=\left(\lambda_{S_{V}}-\lambda_{E_{V}}\right) \sigma_{V}\left(\frac{\beta_{V} I_{V}+\beta_{V H} R_{H}}{N_{H}}\right) S_{V}+\lambda_{I_{H}} I_{V} \\
& u_{1}{ }^{*}=\left(\lambda_{S_{V}}-\lambda_{E_{V}}\right) \sigma_{V}\left(\frac{\beta_{V} I_{V}+\beta_{V H} R_{H}}{N_{H}}\right) S_{V}+\lambda_{I_{H}} I_{V} \\
& C_{1}
\end{aligned}
$$

Karena batasan nilai $u_{1}$ adalah $0<u_{1}<1$, maka diperoleh beberapa kemungkinan hasil yang di dapat yaitu 


$$
u_{1}=\left\{\begin{array}{ccr}
u_{1}{ }^{*}, & \text { jika } & 0<u_{1}{ }^{*}<1 \\
0, & \text { jika } & u_{1}{ }^{*} \leq 0 \\
1, & \text { jika } & u_{1}{ }^{*} \geq 1
\end{array}\right.
$$

Dari beberapa kemungkinan diatas, maka pengontrol yang optimal adalah

$u_{1}=$

$\max \left\{\min \left(\frac{\left(\lambda_{S_{V}}-\lambda_{E_{V}}\right) \sigma_{V}\left(\frac{\beta_{V} I_{V}+\beta_{V H} R_{H}}{N_{H}}\right) S_{V}+\lambda_{I_{H}} I_{V}}{c_{1}}, 1\right), 0\right\}$

b. $\frac{\partial H}{\partial u_{2}}=0$

$C_{2} u_{2}{ }^{*}+\left(\lambda_{I_{H}}-\lambda_{S_{V}}\right) I_{H}=0$

$C_{2} u_{2}^{*}=\left(\lambda_{S_{V}}-\lambda_{I_{H}}\right) I_{H}$

$u_{2}^{*}=\frac{\left(\lambda_{S_{V}}-\lambda_{I_{H}}\right) I_{H}}{C_{2}}$

Karena batasan nilai $u_{2}$ adalah $0<u_{2}<1$, maka diperoleh beberapa kemungkinan hasil yang di dapat yaitu

$$
u_{2}=\left\{\begin{array}{ccr}
u_{2}{ }^{*}, & \text { jika } & 0<u_{2}{ }^{*}<1 \\
0, & \text { jika } & u_{2}{ }^{*} \leq 0 \\
1, & \text { jika } & u_{2}{ }^{*} \geq 1
\end{array}\right.
$$

Dari beberapa kemungkinan diatas, maka pengontrol yang optimal adalah

$$
u_{2}=\max \left\{\min \left(\frac{\left(\lambda_{S_{V}}-\lambda_{I_{H}}\right) I_{H}}{C_{2}}, 1\right), 0\right\}
$$

3. Menentukan $H^{*}$ yang optimal

Dengan mensubtitusikan persamaan (3.2) dan (3.3) ke dalam persamaan (3.1) sehingga diperoleh:

$$
\begin{aligned}
H^{*}= & I_{H}(t)+I_{v}(t)+\left(\frac{\left(\lambda_{S_{V}}-\lambda_{E_{V}}\right) \sigma_{V}\left(\frac{\beta_{V} I_{V}+\beta_{V H} R_{H}}{N_{H}}\right) S_{V}}{C_{1}}+\right. \\
& \left.\frac{\left(\lambda_{S_{V}}-\lambda_{I_{H}}\right) I_{H}+\lambda_{I_{H}} I_{V}}{C_{2}}\right)+\lambda_{S_{H}}\left(\Pi_{H}+\rho_{H} R_{H}-\right. \\
& \left.\sigma_{V} \beta_{H} \frac{I_{V}}{N_{H}} S_{H}-\mu_{H} S_{H}\right)+\lambda_{E_{H}}\left(\sigma_{V} \beta_{H} \frac{I_{V}}{N_{H}} S_{H}-\right. \\
& \left.\left(v_{H}+\mu_{H}\right) E_{H}\right)+\lambda_{I_{H}}\left(v_{H} E_{H}-\left(\gamma_{H}+\mu_{H}+\right.\right. \\
& \left.\left.\delta_{H}\right) I_{H}\right)+\lambda_{R_{H}}\left(\gamma_{H} I_{H}-\left(\rho_{H}+\mu_{H}\right) R_{H}\right)+\lambda_{S_{V}}\left(\Pi_{V}-\right. \\
& \sigma_{V}\left(\frac{\beta_{V} I_{V}+\beta_{V H} R_{H}}{N_{H}}\right) S_{V}-\mu_{V} S_{V}+ \\
& \lambda_{E_{V}} \sigma_{V}\left(\frac{\beta_{V} I_{V}+\beta_{V H} R_{H}}{N_{H}}\right) S_{V}-\left(v_{V}+\mu_{V}\right) E_{V} \lambda_{I_{V}}\left(v_{V} E_{V}-\right. \\
& \left(\mu_{V}\right) I_{V} \quad(4.5 .4)
\end{aligned}
$$

4. Menyelesaikan persamaan state dan costate untuk memperoleh sistem yang optimal

$$
\begin{array}{ll}
\text { a. Persamaan State } \\
\frac{\partial H^{*}}{\partial \lambda_{S_{H}}}=\Pi_{H}+\rho_{H} R_{H}-\sigma_{V} \beta_{H} \frac{I_{V}}{N_{H}} S_{H}-\mu_{H} S_{H} \\
\frac{\partial H^{*}}{\partial \lambda_{E_{H}}}=\sigma_{V} \beta_{H} \frac{I_{V}}{N_{H}} S_{H}-\left(v_{H}+\mu_{H}\right) E_{H} \\
\frac{\partial H^{*}}{\partial \lambda_{I_{H}}}=v_{H} E_{H}-\left(\gamma_{H}+\mu_{H}+\delta_{H}+u_{2}\right) I_{H}
\end{array}
$$

$$
\begin{aligned}
& \frac{\partial H^{*}}{\partial \lambda_{R_{H}}}=\left(\gamma_{H}+u_{2}\right) I_{H}-\left(\rho_{H}+\mu_{H}\right) R_{H} \\
& \frac{\partial H^{*}}{\partial \lambda_{S_{V}}}=\Pi_{V}-\left(1-u_{1}\right) \sigma_{V}\left(\frac{\beta_{V} I_{H}+\beta_{V H} R_{H}}{N_{H}}\right) S_{V}-\mu_{V} S_{V} \\
& \frac{\partial H^{*}}{\partial \lambda_{E_{V}}}=\left(1-u_{1}\right) \sigma_{V}\left(\frac{\beta_{V} I_{H}+\beta_{V H} R_{H}}{N_{H}}\right) S_{V}-\left(v_{V}+\right. \\
& \left.\frac{\partial H^{*}}{\partial \lambda_{I_{V}}}=v_{V}\right) E_{V}+
\end{aligned}
$$

b. Persamaan costate

$$
\begin{aligned}
\frac{\partial \lambda_{S_{H}}}{\partial t} & =-\frac{\partial H^{*}}{\partial S_{H}} \\
& =\left(\lambda_{S_{H}}-\lambda_{E_{H}}\right) \sigma_{V} \beta_{H} \frac{I_{V}}{N_{H}}+\lambda_{S_{H}} \mu_{H} \\
\frac{\partial \lambda_{E_{H}}}{\partial t} & =-\frac{\partial H^{*}}{\partial E_{H}} \\
& =\left(\lambda_{E_{H}}-\lambda_{I_{H}}\right) v_{H}+\lambda_{E_{H}} \mu_{H} \\
\frac{\partial \lambda_{I_{H}}}{\partial t} & =-\frac{\partial H^{*}}{\partial I_{H}} \\
= & -1+\left(\lambda_{I_{H}}-\lambda_{R_{H}}\right) \gamma_{H}+\lambda_{I_{H}}\left(\mu_{h}+\delta_{H}\right) \\
\frac{\partial \lambda_{R_{H}}}{\partial t}= & -\frac{\partial H^{*}}{\partial R_{H}} \\
= & \left(\lambda_{R_{H}}-\lambda_{S_{H}}\right) \rho_{H}+\left(\lambda_{S_{V}}-\lambda_{E_{V}}\right) \frac{\beta_{V H}}{N_{H}} S_{v}+ \\
& \lambda_{R_{H}} \mu_{H} \\
\frac{\partial \lambda_{S_{V}}}{\partial t}= & -\frac{\partial H^{*}}{\partial S_{V}} \\
= & \left(\lambda_{S_{V}}-\lambda_{E_{V}}\right) \sigma_{V}\left(\frac{\beta_{V} I_{H}+\beta_{V H} R_{H}}{N_{H}}\right)+\lambda_{S_{V}} \mu_{V} \\
\frac{\partial \lambda_{E_{V}}}{\partial t}= & -\frac{\partial H^{*}}{\partial E_{V}} \\
= & \left(\lambda_{E_{V}}-\lambda_{I_{V}}\right) v_{V} \mp \mu_{V} \\
\frac{\partial \lambda_{I_{V}}}{\partial t}= & -\frac{\partial H^{*}}{\partial I_{V}} \\
= & \left(\lambda_{S_{H}}-\lambda_{E_{H}}\right) \sigma_{V} \beta_{H} \frac{S_{H}}{N_{H}}+\left(\lambda_{S_{V}}-\lambda_{E_{V}}\right) \frac{\beta_{H}}{N_{H}} S_{v}+ \\
& \lambda_{I_{V}} \mu_{V}
\end{aligned}
$$

\section{Analisis Hasil Simulasi}

Penyelesaian kontrol optimal sulit diselesaikan secara analitik sehingga pada penyelesaian kontrol optimal ini diselesaikan secara numerik. Hal ini dilakukan dengan mensimulasikan permasalahan kontrol optimal menggunakan metode Range-Kutta Orde 4 dengan nilai awal dan parameter seperti pada Tabel 1 dan Tabel 2.

Dengan pemberian kontrol $u_{1}(t)$ yaitu kontrol terhadap penyemprotan insektisida untuk dapat meminimumkan jumlah populasi nyamuk, dan kontrol $u_{2}(t)$ yaitu kontrol untuk pengobatan individu yang sudah terinfeksi, didapatkan hasil simulasi yang dapat dilihat pada Gambar 2.

Gambar 2 menunjukan perbedaan jumlah sub-populasi manusia Exposed sebelum dan sesudah dikontrol. Sub-po pulasi manusia Exposed sebelum di kontrol dengan kondisi awal $E_{H}(0)=200$, seiring waktu populasi manusia Exposed menurun, kemudian stabil dari waktu 45 dengan jumlah manusia manusia Exposed 30 orang. Hal ini, disebabkan karena populasi Exposed berubah menjadi poulasi Infected. Sedangkan, ketika sub-populasi manusia Exposed tersebut 


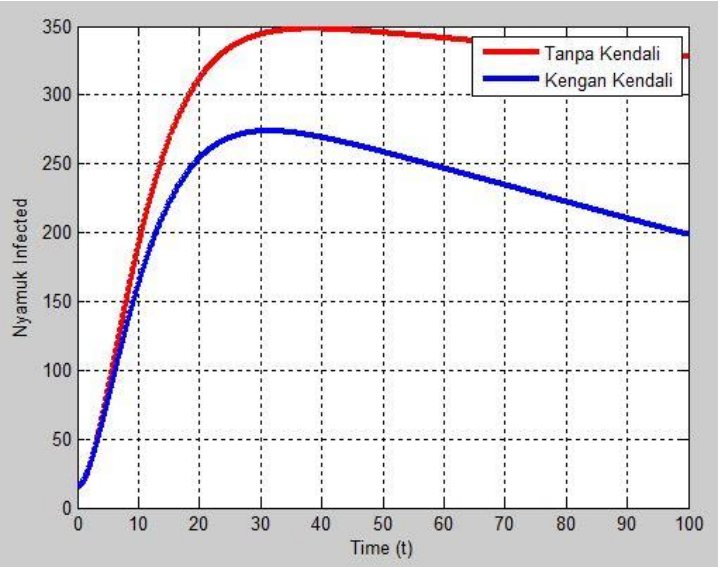

Gambar 6. Grafik sub-populasi nyamuk infected sebelum dan sesudah dikontrol.

diberikan kontrol $u_{1}(t)$ dan $u_{2}(t)$ terjadi penurunan secara cepat sampai waktu ke 20 dengan jumlah populasi manusia Exposed 20 orang, kemudian menaik sampai waktu ke 44 dengan jumlah populasi manusia Exposed 24 orang dan kemudian grafik menunjukan penurunan secara berangsur sampai waktu ke 100 jumlah populasi Exposed 19 orang. Ini berarti pemberian kontrol $u_{1}(t)$ dan $u_{2}(t)$ efektif dalam mengurangi jumlah sub-populasi manusia yang telah terinfeksi penyakit malaria namun gejala yang ditimbulkan belum tampak.

Gambar 3 menunjukan perbedaan jumlah sub-populasi manusia Infected sebelum dan sesudah dikontrol. Sub-populasi manusia Infected sebelum di kontrol dengan kondisi awal $I_{H}(0)=10$ meningkat pada saat kurang lebih 10 hari akibat terinfeksi malaria sehingga jumlah manusia Infected menjadi 178 orang, kemudian menurun sampai hari ke-100 sehingga jumlah manusia Infected tersebut menjadi 114 orang. Sedangkan, ketika sub-populasi manusia Infected tersebut diberikan kontrol $u_{1}(t)$ dan $u_{2}(t)$ terjadi kenaikan juga smapai waktu ke 10 dengan jumlah populasi Infected 137 orang yang lebih kecil dari populasi manusia Infected. Namun setelah itu populasi manusia Infected mengalami penurunan secara berangsur sampai waktu ke 100 dengan jumlah populasi manusia Infected yaitu 84 orang, yang mana populasi manusia Infected lebih sedikit dari sebelum dikontrol. Ini berarti pemberian kontrol $u_{1}(t)$ dan $u_{2}(t)$ efektif dalam mengurangi jumlah sub-populasi manusia yang telah terinfeksi penyakit malaria.

Gambar 4 menunjukan perbedaan jumlah sub-populasi manusia Susceptible sebelum dan sesudah dikontrol. Subpopulasi nyamuk Susceptible sebelum di kontrol dengan kondisi awal $S_{H}(0)=600$ menurun pada saat kurang lebih selama 4 hari akibat terjangkit penyakit malaria sehingga jumlah nyamuk Susceptible menjadi 560 dan kemudian meningkat sampai hari ke-100 hingga jumlah nyamuk Susceptible menjadi 675. Sedangkan, ketika sub-populasi manusia Susceptible tersebut diberikan kontrol $u_{1}(t)$ dan $u_{2}(t)$ terjadi kenaikan lebih cepat sampai jumlah manusia Susceptible menjadi 1002 orang.. Jadi, jumlah sub-populasi nyamuk Susceptible tersebut bertambah dengan pesat daripada tanpa adanya pengontrolan. Ini berarti pemberian kontrol $u_{1}(t)$ dan $u_{2}(t)$ efektif dalam memaksimalkan jumlah sub- populasi manusia sehat atau rentan dalam penyebaran penyakit malaria.

Gambar 5 menunjukan perbedaan jumlah sub-populasi nyamuk Susceptible. Sub-populasi nyamuk Susceptible sebelum di kontrol dengan kondisi awal $S_{V}(0)=7050$ menurun sampai waktu ke 46 hari dengan populasi nyamuk Susceptible sebanyak 6616 ekor dan kemudian mengalami peningkatan sampai waktu ke 100 dengan jumlah populasi nyamuk Susceptible sebanyak 6640 ekor, ini terjadi karena nyamuk terinfeksi parasite Plasmodium Sedangkan, ketika sub-populasi nyamuk Infected tersebut diberikan kontrol $u_{1}(t)$ dan $u_{2}(t)$ terjadi menurun sampai waktu ke 30 hari dengan populasi nyamuk Susceptible sebanyak 6790 ekor dan kemudian mengalami peningkatan sampai waktu ke 100 dengan jumlah populasi nyamuk Susceptible sebanyak 6866 ekor. Ini berarti pemberian kontrol $u_{1}(t)$ dan $u_{2}(t)$ efektif dalam memaksimalkan jumlah sub-populasi nyamuk sehat atau rentan dalam penyebaran penyakit malaria.

Gambar 6 menunjukan perbedaan jumlah sub-populasi nyamuk Infected. Sub-populasi nyamuk Infected sebelum di kontrol dengan kondisi awal $I_{V}(0)=15$ mengalami kenaikan sampai waktu kurang lebih ke 38 dengan jumlah populasi nyamuk Infected sebanyak 348 ekor, dan setelahnya mengalami kenaikan sampai waktu ke 100 dengan jumlah populasi Infected sebanyak 327 ekor. Sedangkan, ketika subpopulasi nyamuk Exposed tersebut diberikan kontrol $u_{1}(t)$ dan $u_{2}(t)$ terjadi kenaikan sampai waktu kurang lebih ke 31 dengan jumlah populasi nyamuk Infected sebanyak 274 ekor, dan setelahnya mengalami penurunan secara drastis sampai waktu ke 100 dengan jumlah populasi Infected sebanyak 197 ekor, yang mana jumlah ini lebih sedikit dari populasi nyamuk Infected tanpa adanya kontrol. Ini berarti pemberian kontrol $u_{1}(t)$ dan $u_{2}(t)$ efektif dalam memaksimalkan jumlah subpopulasi nyamuk yang telah terinfeksi parasit plasmodium namun gejala yang ditimbulkan belum tampak.

Dari hasil simulasi, didapatkan nilai fungsi objektif $(J)$ dengan dan tanpa kontrol adalah sebagai berikut

\begin{tabular}{|l|l|}
\hline Simulasi & Hasil Fungsi Objektif \\
\hline Simulasi tanpa kontrol & 10.9144 \\
\hline Simulasi dengan kontrol & 1.5556 \\
\hline
\end{tabular}

Dari hasil perhitungan fungsi objektif dapat diamati bahwa simulasi dengan kontrol memiliki nilai fungsi objektif yang lebih kecil dibandingkan dengan simulasi tanpa kontrol. Ini berarti pemberian kontrol yang dilakukan dapat meminimumkan fungsi objektif dimana dalam hal ini fungsi objektif yang dimaksudkan adalah biaya yang dikeluarkan. Jika nilai fungsi objektif rendah, maka biaya yang dikeluarkan juga rendah, begitu juga sebaliknya. Jadi, dengan adanya pemberian kontrol, selain dapat meminimumkan penyebaran penyakit malaria, pengeluaran biaya yang dibutuhkan juga dapat diminimumkan.

\section{KESIMPULAN}

Berdasarkan analisis dan pembahasan yang telah dibahas pada bab sebelumnya, maka diperoleh kesimpulan sebagai berikut:

1. Sistem dinamik pada model penyebaran penyakit malaria diperoleh 2 titik kesetimbangan yaitu: 

a. Titik setimbang non endemik $E_{0}=$ untuk pengobatan individu yang sudah terinfeksi, jika $u_{2}(t)=$ $\left(\frac{\Pi_{H}}{\mu_{H}}, 0,0,0, \frac{\Pi_{V}}{\mu_{V}}, 0,0\right)$$$
\frac{\left(\lambda_{S_{V}}-\lambda_{I_{H}}\right) I_{H}+\lambda_{I_{H}} I_{V}}{C_{2}} \text {. }
$$
b. Titik setimbang endemik

$$
E=\left(S_{H}^{*}, E^{*}{ }_{H}, I_{H}^{*}, R_{H}^{*}, S_{V}^{*}, E^{*}{ }_{V}, I^{*}{ }_{V}\right)
$$
dengan:

$$
\begin{aligned}
S^{*}{ }_{H} & =\frac{\Pi_{H}\left(\Pi_{H}+\rho_{H}\right) R^{*}{ }_{H}}{\sigma_{V} \beta_{H} \mu_{H} I^{*}{ }_{V}-\mu_{H} \Pi_{H}} \\
E^{*}{ }_{H} & =\frac{\sigma_{V} \beta_{H} \mu_{H} I^{*}{ }_{V}}{\prod_{H}\left(v_{H}+\mu_{H}\right)} S^{*}{ }_{H} \\
I^{*}{ }_{H} & =\frac{v_{H} E^{*}{ }_{H}}{\gamma_{H}+\mu_{H}+\delta_{H}+u_{2}} \\
R^{*}{ }_{H} & =\frac{\left(\gamma_{H}+u_{2}\right) I^{*}{ }_{H}}{\rho_{H}+\mu_{H}} \\
S^{*}{ }_{V} & =\frac{\Pi_{V}{ }^{2}}{\left(1-u_{1}\right) \sigma_{V} \mu_{H}\left(\beta_{V} I^{*}{ }_{H}+\beta_{V H} R^{*}{ }_{H}\right)-\mu_{V} \Pi_{H}} \\
E^{*}{ }_{V} & =\frac{\left(1-u_{1}\right) \sigma_{V} \mu_{H}\left(\beta_{V} I^{*}{ }_{H}+\beta_{V H} R^{*}\right) S^{*}{ }_{V}}{\Pi_{V}\left(v_{V}+\mu_{V}\right)} \\
I^{*}{ }_{V} & =\frac{v_{V} E^{*}{ }_{V}}{\mu_{V}+u_{1}}
\end{aligned}
$$

3. Dengan pemberian kontrol kontrol penyemprotan insektisida dan kontrol pengobatan individu terinfeksi, didapatkan dinamika jumlah sub-populasi manusia yang terinfeksi malaria dan jumlah populasi nyamuk terinfeksi parasit Plasmodium juga menurun dibandingkan dengan sebelum diberikan kontrol. Selain itu juga, didapatkan nilai fungsi objektif dengan adanya kontrol yang lebih kecil dibandingkan dengan nilai fungsi objektif tanpa adanya kontrol. Ini berarti dengan adanya pemberian kontrol, selain dapat meminimumkan penyebaran penyakit malaria, pengeluaran biaya yang dibutuhkan juga dapat diminimumkan.

\section{DAFTAR PUSTAKA}

[1] J. Tumwiine, J. Y. T. Mugisha, and L. S. Luboobi, “A mathematical model for the dynamics of malaria in a human host and mosquito vector with temporary immunity," Appl. Math. Comput., vol. 189, no. 2, pp. 1953-1965, Jun. 2007.

[2] WHO (World Health Organization), "World Malaria Report 2011," 2011.

2. Kendali optimal yang diperoleh pada upaya pemaksimalan atau peningkatan individu manusia yang sehat namun rentan dengan menerapkan Prinsip Maksimum Pontryagin didapat pengendali berupa pemberian kontrol $u_{1}(t)$ yaitu kontrol terhadap penyemprotan insektisida untuk dapat meminimumkan jumlah populasi nyamuk, jika nilai $u_{1}(t)=$ $\frac{\left(\lambda_{S_{V}}-\lambda_{E_{V}}\right) \sigma_{V}\left(\frac{\beta_{V} I_{H S}+\beta_{V H} R_{H}}{N_{H}}\right) S_{V}}{C_{1}}$, dan kontrol $u_{2}(t)$ yaitu kontrol

[3] L. Hakim, "Malaria: Epidemiologi dan Diagnosis Malaria: Epidemiology and Diagnostic."

[4] P. Roop-O, W. Chinviriyasit, and S. Chinviriyasit, "The effect of incidence function in backward bifurcation for malaria model with temporary immunity," Math. Biosci., vol. 265, pp. 47-64, Jul. 2015.

[5] A. A. Momoh and A. Fügenschuh, "Optimal control of intervention strategies and cost effectiveness analysis for a Zika virus model," Oper. Res. Heal. Care, vol. 18, pp. 99-111, Sep. 2018.

[6] L. Perko, "Differential Equations and Dynamical Systems," USA, 2001.

[7] D. S. Naidu, Optimal Control Systems. USA: CRC Press LLC, 2002. 